\title{
Stereotypes: An obstacle or trigger to business success?
}

\author{
Julianna Nádai ${ }^{1}$
}

\begin{abstract}
The present paper focuses on the role of existing stereotypes in business negotiation processes. How can stereotypes help or prevent us from successful negotiating between two nations? Stereotypes are a core research topic when dealing with business relations and corporate behavior. I will give an overview of how much stereotypical way of thinking can motivate businesspeople to find business partners in other countries and how much they are a barrier in launching deals. Stereotypes are claimed to be mostly negative but most of them are based without any experience while others are constructed as a result of direct interactions. In the paper I am describing decision mechanisms derived from stereotypical knowledge of the business partners. And next, I will focus on the decisions made on various elements in a business process like attitudes to information gained from the partner, payment system or selecting partners, which are influenced by existing stereotypes of each negotiator. The paper also reveals how shared values of different cultures can lead to successful or failed negotiations in terms of Hungarian and German business relations.
\end{abstract}

Key Words: Stereotypes, negotiations, cultures, success, attitude

\section{Introduction}

The ever increasing number of small and medium enterprises in the world and all over Europe it has become crucial to take cultural concerns into account beside focusing just on business success. That is why the study of corporate culture and intercultural communication are central to deal with as a discipline. Due to the complex network of business relations it is hard to find the best way and knowledge to find proper partners to make deals with. The number of nations appearing on the market requires from negotiators to be more than just business oriented people, as they also need to be aware of cultural specifics and culture adapted behavior styles (Ablonczy and Tompos 2009) during negotiations. In the paper I assume that it occurs from time to time that cultural differences are ignored and stereotypical way of thinking, generalizations distort the results of deals.

\section{Methodology}

As the present study is an exploratory and diagnostic research, the basic research method is rooted in literature overview and semi-structured interviews with German and Hungarian management of German oriented companies. A basic aim is to give a detailed descriptive analysis of behaviors where we wished to explain typical reasons for attitudes to another culture and to see how much stereotypes influence contracting willingness. The present study can also be regarded as an explanatory research. In the interviews 
questions are asked both from Hungarian and German managers about their previous experience with deals with the other nations and also projections they connect to the nations they deal with. In the interviews we asked 14 middle managers and CEOs of German oriented companies seated in the Western Hungarian region.

The method of semi-structured interview is proper for the present research as it provides an open framework for research. The questions are also formulated during the interviews depending on the answers of the respondents. During the face-to-face interview the interviewer has the chance to interpret and ask for clarifying as well. They are also given the opportunity to get and give information on the current issue (Babbie, 2013; Andorka, 2002; Héra and Ligeti, 2006). During the interview we can verify the content of what is said reflecting the respondents' verbal and nonverbal or metacommunication (Geertz, 2008). The respondents usually tend to give answers instinctively which they deem to be expected and this way they project a standard idealistic view of their attitudes. These answers can be tackled easier than doing so in surveys.

The interviewers were selected on the base of stratified sampling, according to the size of company (medium size companies) and to the fact if they have negotiated with partners from the other nation (that is Germans or Hungarians). The number of respondents is limited at the current phase of research (14 respondents) as we are still constantly increasing the number of interviewees to reach a more realistic research result.

In the present study I am focusing on deals with relations between German and Hungarian companies and enterprises because the two countries have a long business relation history. In Hungary there are plenty of company seats with German ownership, $16 \%$ of all foreign companies, at the same time economic performance rate of companies with German ownership takes about 32\% (http://www.ksh.hu/stadat). Business relations have been multiplied since the EU accession of Hungary (2004). Due to the high quality level of Hungarian service companies there is a great demand for Hungarians working for German companies. Of course, the EU accession made business transactions easier according to the basic rights to free movement of goods, services persons and capital.

(http://ec.europa.eu/geninfo/query/resultaction.jsp?QueryText $=$ free + movement + of + capital\&s btSearch=Search\&swlang $=$ hu $)$.

Table 1 International Affiliation in Hungary, 2015

\begin{tabular}{|l|l|}
\hline Investing Countries & Percentage (\%) \\
\hline Austria & 15 \\
\hline France & 4 \\
\hline Germany & $\mathbf{1 6}$ \\
\hline Italy & 4 \\
\hline Liechtenstein & 3 \\
\hline Netherlands & 6 \\
\hline Other countries & 25 \\
\hline Seychelles & 4 \\
\hline Switzerland & 5 \\
\hline United Kingdom & 6 \\
\hline United States of America & 12 \\
\hline Soure:
\end{tabular}

Source: www.ksh.hu 


\section{Stereotypes, prejudices, attitudes}

When negotiations take place in international context between different nations the parties have a specific mindset and attitude toward the culture they encounter at deals. Their ideas of another culture may be set on a cognitive and emotional basis (Nádai 2006).

Intercultural studies must not avoid the issue of stereotypes. According to Allport (1999) stereotypes are 'a generalized set of beliefs about a group of people.' Another definition describes stereotypes as a kind of ethnocentrism i.e. 'it is the belief in the intrinsic superiority of the culture to which one belongs, accompanied by feelings of dislike and contempt to other cultures.' According to an American linguist, Joyce Valdes, people are culture bound and do not see the confines of their own culture. "Most people of whatever nation, see themselves and their compatriots not as culture but as 'standard' or 'right', and the rest of the world as made up of cultures." (Katan, 1999) Forming stereotypes of a different culture may lead to misunderstandings as these are often based on experience with an individual of the community and do not regard any individual as an exception. Concerning all the definitions it is clear that stereotypes are generalized in a cognitive way and are projections to a group of some common interest or to the individuals of the group, based on personal experience.

It is hard to distinguish stereotypes and prejudices as they have common roots. Prejudices often appear within stereotypes but we have to make a clear distinction. While stereotypes have a cognitive basis, prejudices emerge out of emotions as affective generalizations and may lack any personal encounter or experience. Allport reflects prejudice as 'an antipathy based on faulty and inflexible generalization. It may be felt or expressed. It may be directed toward a group as a whole or toward an individual because he is a group member' (Allport). According to literature we can accept that attitudes have cognitive, affectionate and behavioral components where stereotypes are the cognitive components. Both prejudices and stereotypes may develop on the following fields: age, disability, religion, ethnicity, economy, social status, nations, races, physical appearance etc.

There exist positive and negative stereotypes in our consciousness about the behavior and habits of cultures (Crystal, 2003). According to Eagly and Chaiken (1993), attitude is a psychological tendency deeming a certain entity to be negative or positive.

Ethnocentrism mainly occurs at the level of the community, deeming one's own culture as the center of all cultures. This phenomenon is typical of people who do not often encounter foreigners. According to Hofstede (1991) ethnocentrism and negative stereotypes in the mind turn into polycentrism for those who are regularly exposed to foreigners. These people can recognize that cultures are different but equal. Polycentrism regards phenomenon, behavior of members of foreign cultures is regarded as much better than that of one's own culture.

'Subjective culture refers to the experience of the social reality formed by a society's institutions-in other words, the worldview of a society's people' (Bennett M. J. 2003). So cultural generalization must be applied to individuals as tentative hypotheses, open to verification. Thus, generalizations cannot be made without a deep research into a culture (Bennett 2003). 
Hofstede (2010) created a model for distinguishing two kinds of stereotypes based on self-perception and mutual perception of cultural communities: auto- and heterostereotypes.

- What we think of ourselves, that is our self-image, depends on upbringing, personal (Hidasi, 2005) experience and others' reaction to our behavior.

- What we think of others is influenced by our cultural background, education and upbringing. We have limited knowledge of other cultures since information comes from the media and newspapers in a filtered form lacking the most significant points. Communication channels like television and newspapers often present a distorted picture about a different culture.

- What others think of us is mostly based on historical events which generally result in a negative stereotypical idea of the opponent nation.

- What two culture groups think of each other is fostered by cultural and historical background knowledge and actual direct political and commercial relations. Stereotypes in this case cannot be judged as something negative, since awareness of stereotypes may help prevent communication failures.

The reason why various business talks and actions can fail roots in different expectations, stereotypes, bad experience or lack of personal experience, lack of cultural sensitivity or, of course, diverse business concerns (Szőke and Kecskés 2015). One must not forget that not all failures are due to cultural differences, merely economic and business concerns can result in unsuccessful negotiations.

One might think that profit and success orientation motivates businessmen to have a deep insight into and enough information of a potential business partner form another nation. Reality sometimes proves to be the opposite as many negotiators ignore cultural factors when they are about to make deals.

Stereotypes strongly influence business partners' attitude toward the other culture and this way they also affect their behavior at face-to-face meetings (Ablonczy 2014, Tompos 2014).

\section{Problem solving}

We have seen from the previous theories and assumptions that negative or positive stereotypes might distort expectations from the business partners. That is why we have to find solutions for improving preliminary approaches to negotiations with another culture.

At the research we examined bilateral categories to identify the basic differences between German and Hungarian small and medium sized enterprises. Beside stereotypes the term cultural standard was introduced. Compared to stereotypes cultural standards are based on personal experience (Topcu 2005) and determine the way we think of and interpret our and other nations' behavior. We can apply these standards to a set of situations where managers from different cultures have to encounter and make agreements. To set up the categories it is necessary to put the negotiations into a cross-cultural context. Personal involvement is absolutely needed to define the standard categories as they are not simple suggestions based on stereotypes. 
Since the present paper highlights the most important points of a current research and the interviews are still being evaluated, I will give an overview of the most typical experience of stereotypes by the respondents.

Comparing German and Hungarian corporate culture and attitude to business partners form another nation the following categories are made (for example):

- discipline at work - flexibility at work: German managers tend to keep discipline at work and deadlines are also kept. To be precise may seem kind of exaggeration in Hungarians' eyes and is considered as a stereotype of German businessmen. On the other hand, while Hungarians' autostereotype of their flexibility is taken as a positive character, German business partners take it for a sign of some kind of unreliability (for example in case of keeping deadlines, working hours). These generalizations fail when it comes to single business contracts.

- formal communication - informal communication: Due to the strong hierarchy system in Hungary managers expect respect and tend to define exactly what the employees should do. Although it is true that creativity in crucial situations is also typical of Hungarian businessmen. Germans do not have a strict hierarchy system and they have a flat corporate culture, their communication seems also formal (for example addressing people by surnames and Herr/Frau - Sir/Madam).

- non-material motivation - material motivation: Material motivation is a key point for Hungarians because of desiring better living conditions and establishing a stable financial background. The Germans seem to worry less about financial situation. Money orientation is a critical point in generalizations as former East-bloc countries are considered to be more financial focused than Western ones which assumption can be challenged at real business deals

- $\quad$ specific culture - diffuse culture: Hungarians tend to connect business meetings with personal talks and freetime activities while Germans do not mix personal and working spheres. According to the respondents this statement proved to be the most realistic based on everyday business experience.

The rapidly changing global environment enforces the entrepreneurs to improve their business competences by learning from past experience and present practices, and adapting new competences to future perspectives. These competences make a complex system of knowledge, skills, abilities and personal characteristics which, combined, lead to an effective performance (Connerley, 2005). To be effective enough in a multicultural environment, the list must also include intercultural sensitivity. Aycan (1997) adds that in-depth business and technical knowledge, managerial competences and willingness to integrating multiple perspectives are also inevitable. And also, one should take communication effectiveness into account as a key factor of successful business negotiations. According to Rosen and Digh (2001) managers and/or negotiators can be successful if they are globally literate:

'To be globally literate means seeing, thinking, acting, and mobilizing in culturally mindful ways. It's the sum of attitudes, beliefs, knowledge, skills, and behaviors needed for success in today's multicultural global economy' (Rosen and Digh, 2011, p.74).

Rosen emphasizes the following competences as key factors to be possessed by negotiators: 
- $\quad$ Personal literacy (understanding and valuing oneself)

- $\quad$ Social literacy (engaging and challenging other people)

- $\quad$ Business literacy (focusing and mobilizing one's organization)

- $\quad$ Cultural literacy (valuing and leveraging cultural differences)

To grasp stereotypes and avoid the negative effects of behaving according to existing stereotypes you have to be aware of the following three criteria (Hidasi, 2005):

- Self-analysis: reactions to certain experiences depend on emotional attitudes.

- Learning: the best way to avoid generalizations is learning. By this process students are able to distinguish and accept various cultures and values.

- Objective attitude: after discarding old measure tools and value judgment we have to assume an objective stance. Value judgment does not help furthering intercultural communication (Katan, 1999).

If one is motivated and determined enough to keep all the necessities listed above in mind, stereotypical ways of thinking can turn to an open mindset and negotiators can be aware of the danger of making generalistaions base on the nationality of the business partners. Although German and Hungarian negotiators have a long history of business contacts, still there are some concerns and ideas of what will happen at meetings. So, the assumptions of misleading character of stereotypes do exist and using much more appropriate categories based on experience can trigger blooming business relations.

\section{Conclusion}

In the study I highlighted the most important steps of a research on the effect of stereotypical way of thinking on business negotiations, which is still in process and evaluation is being done. Culture specific orientation is a key point when it comes to business negotiations between representatives of two (or more) cultures. The attitudes can be influenced by a stereotypical approach to the business meetings which can be an obstacle of success as they lack any experience and are combined with usually negative prejudice of the partner's national background. It was necessary to use bilateral categories to help the respondents give impressions on their business partners. These so called cultural standards can prevent businessmen from thinking in terms of stereotypes, besides we made some suggestions to involve techniques to improve cultural sensitivity. Our research has go limitations which must be considered in the future, such as the number of respondents should be extended and also the number of nationalities examined should be raised to get a more reliable picture of current situation.

\section{References}

Ablonczyné M. L., Tompos A. (2009). Szociokulturális kompetencia és sztereotípiák: hogyan tárgyalunk külfölldiekkel? * Translatologia Pannonica *3(1): 81-89.

Ablonczyné M. L. (2014). When in Rome do as the Romans do: is it a reality of business life? In: Rotschedl, J. - Cemakova, K. (ed.) Proceedings of the 14th International Academic Conference. Prague: International Institute of Social and Economic Sciences, 2014. pp. 1-9. (ISBN:978-80-87-927-06-9)

Allport, G. W. (1999). Az elöitélet. Budapest: Osiris Kiadó 
Andorka, R. (2002). Bevezetés a szociológiába. Budapest: Osiris Kiadó

Aycan, Z. (1997). Expatriate Management: Theory and Research. Greenwich, CT: JAI

Babbie, E. (2013). The practice of social research. Wandsworth: Cengage Learning

Bennett, J.M., Bennett, M.J. (2003). Developing intercultural sensitivity. Retrieved from: http://itu.dk/courses/projectcluster/GITU/F2008/reading/Developing intercultural sensitivity. pdf

Connerley, M. L., Pedersen, P. B. (2005). Leadership in a Diverse and Multicultural Environmanet. Developing Awareness, Knowledge, and Skills. Thousand Oaks, Sage Publications:London

Crystal, D. (2003), The Cambridge Encyclopedia of Language. Cambridge, Cambridge University Press.

Eagly, A. H., Chaiken, S. (1993), The Psychology of Attitudes. Cengage Learning, United Kingdom

Geertz, C. (2008). Dichte Beschreibung. Bemerkung zu einer bedeutenden Theorie von Kultur. In: Wirth, U. (ed.): Kulturwissenschaften. Frankfurt am Main: Suhrkamp Verlag,

Héra G., Ligeti, Gy. (2006). Módszertan. A társadalmi jelenségek kutatása. Budapest: Osiris Kiadó

Hidasi, J. (2005). Intercultural Commnication. An Outline. Tokyo: Sangensha

Hofstede, G. (1991). Cultures and Organisations: Software of the Mind. London: McGrow-Hill.

http://www.ksh.hu/stadat (12 March 2015)

http://ec.europa.eu/geninfo/query/resultaction.jsp?QueryText $=$ free + movement + of + capital\&sbtSearch $=\mathrm{S}$ earch\&swlang $=$ hu

Katan, D. (1999). Translating Cultures. Manchester: St Jerome Publishing.

Nádai, J. (2006). New Approaches to Teaching and Researching Intercultural Communication and Stereotypes. Trans: Internet Journal for Cultural Studies. Nr. 16., pp. 11-16. Retrieved from: http://www.inst.at/trans/16Nr/07 3/nadai16.htm (11 April 2014)

Rosen, R., Digh, P. (2001). Developing globally literate leaders. Training and Development, 55(5), 70-81

Szőke, J., Kecskés, P. (2015). Bízzak vagy ne bízzak?: A sztereotípiák hatása a vállalati kapcsolatokra In: Tompos, A., Ablonczyné, M. L. (ed.) "Kitekintések - 25 éves a gyớri közgazdásžeépzés": Kautz Gyula Emlékekonferencia. Győr, Hungary, 11.06.2015 Győr: Széchenyi István University, Faculty of Economics Kautz Gyula, 2015. Paper 6 p. (ISBN:978-615-5391-70-5)

Tompos, A. (2014). Hungarian societal values through business negotiators' practices. In: Rotschedl, J. and Cermakova, K.(eds.) *Proceedings of the 14th International Academic Conference.* Prague: International Institute of Social and Economic Sciences. pp. 445-453. ISBN 978-80-87927-06-9 ISSN 23365617 (e-book)

Topcu, K. (2005). A kulturstandard-kutatás elmélete és gyakorlata magyar-osz̨trák menedžser-interakciókban: egy magyar szempontú elemzés. Doctorate thesis. Budapesti Corvinus Egyetem, Budapest. Retrieved from: http://phd.lib.uni-corvinus.hu/216/1/topcu katalin.pdf (10 April 2016) 